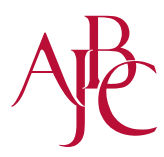

\title{
Protective Effects of Ellagic Acid against UVA- induced Oxidative Stress in Human Dermal Papilla
}

\author{
Kyung-Suk Kim ${ }^{1}$, Song Hee $\mathrm{Han}^{2}$, In-Sook An ${ }^{3}$, Kyu Joong $\mathrm{Ahn}^{2 *}$ \\ ${ }^{1}$ Department of Biological Engineering, Konkuk University, Seoul, Korea \\ ${ }^{2}$ Department of Dermatology, Konkuk University School of Medicine, Seoul, Korea \\ ${ }^{3}$ Korea Institute for Skin and Clinical Sciences, Cheongju-si, Chungcheongbuk-do, Korea
}

*Corresponding author: Kyu Joong Ahn, Department of Dermatology, Konkuk University School of Medicine, 120

Neungdong-ro, Gwangjin-gu, Seoul 05029, Korea

Tel.: +82 220305181

Fax: +82 220305179

Email:kjahn@kuh.ac.kr

Received May 16, 2016

Revised June 7, 2016

Accepted June 8, 2016

Published June 30, 2016

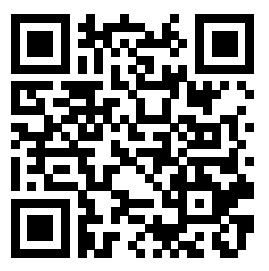

\begin{abstract}
Purpose: One of solar radiation components, ultraviolet A (UVA), has deeply penetrating capacity and generates reactive oxygen species (ROS) in the skin. These characteristics arouse oxidative stress in dermis, such as photoproducts, senescence, cell death, inflammation, and alterative gene expression. Thus, UVA is considered a major factor of external stimuli that irritates the skin. This study aimed at investigating the antioxidant and anti-inflammatory effects of ellagic acid on UVAirradiated human dermal papilla cells (HDPCs). Methods: The cell viability of HDPCs were analyzed using the water-soluble tetrazolium salt (WST-1) assay. 2,7-dichlorofluorescin diacetate (DCFH-DA) was used in evaluating intracellular ROS scavenging activity. All the mRNA expression levels were carried out via quantitative real-time polymerase chain reaction ( $\mathrm{qRT}-\mathrm{PCR})$. Cellular senescence was evaluated using senescence-associated $\beta$-galactosidase $(\mathrm{SA}-\beta$-gal) staining kit. The wound healing assay in HDPCs were performed to assess effects of ellagic acid on the cell migration activity. Results: No cell cytotoxicity of ellagic acid was observed at concentration up to $25 \mu \mathrm{M}$. In irradiated HDPCs, ellagic acid showed protective effects on UVA-induced cytotoxicity. Further, ellagic acid represented ROS scavenging activity and regulating antioxidant gene expression, catalase transcriptional levels under UVAirradiated condition. It also modulated tumor necrosis factor alpha $(T N F-\alpha)$ and interleukin $6(I L-6)$ mRNA expresison levels and cellular senescence on UVA-stimulated HDPCs. Cell migration assay showed the protective effects of ellagic acid on movement of HDPCs damaged by UVA. Conclusion: These results demonstrate that ellagic acid protects UVA-induced oxidative stress in HDPCs.
\end{abstract}

Keywords: UVA, Oxidative stress, Human dermal papilla, Inflammation, Ellagic acid

\section{Introduction}

태양광은 3 가지 유형의 자외선으로 구성되어 있다. 자외선 은 그 파장에 따라 ultraviolet A (UVA), ultraviolet B (UVB), ultraviolet C (UVC)로 나뉘는데, 이중에서도 가장 긴 파장대 (320-400 nm)를 가지고 있는 UVA는 지표면에 도달하는 자 외선의 $95 \%$ 이상을 차지하고 있으며 깊은 투과력으로 피부 진 피층까지 침투하여 활성산소를 생성하고 장기적으로는 피부
손상과 노화를 유발한다(Wondrak et al., 2003; Bickers \& Athar, 2006; Cha \& Kim, 2015; Kim et al., 2015). 자외선 에 의해 생성된 활성산소는 세포 내에서 DNA를 손상시키거나 염증반응을 유도하기도 하고, 유전자 발현에도 영향을 끼치는 것으로 알려져 있다(Vile \& Tyrrell, 1995).

인간 모유두 세포(human dermal papilla cell, HDPC)는 섬유아세포의 일종으로 주기적으로 재생되며 모낭의 발달을 조 절하는데 결정적인 역할을 하는 것으로 알려져 있다 (Inui et 
al., 2003; Gao et al., 2008; Shin et al., 2016). 모유두 세포 는 모낭에 영양을 공급하고 성장조절인자를 분비하여 모낭의 발달과 성장을 조절하는 세포로 모낭하부에 위치하고 있으며 (Driskell et al., 2011) 모발 생성 주기를 직접적으로 조절한다 (Choi et al., 2012). 이러한 이유로 탈모와 관련된 많은 연구에 모유두 세포가 주로 연구되고 있다.

Ellagic acid는 과일과 견과류, 녹차 등에서 발견되는 폴리 페놀 성분으로 인간 섬유아 세포에서 광자극에 의한 손상과 세포 외 기질을 구성하는 콜라겐 발현 조절에 대한 선행연구가 있 다(García-Niño \& Zazueta, 2015; Soong \& Barlow, 2006; Plundrich et al., 2013). 인간과 동물을 대상으로 생물학적 이 용성을 탐구한 연구는 매우 드물지만 선행연구보고에 따르면, 돌연변이, 유전자독성, 세포자살과 악성종양을 저해하고 이 밖 에도 항균, 항바이러스 등의 효과와 질병과 관련해서는 말라 리아, 간질, 당뇨, 신경보호 등에 유효한 효과를 보인 것으로 알 려져 있다(Zahin et al., 2014; Rehman et al., 2012; Li et al., 2005; Khanduja et al., 2006; Abuelsaad et al., 2013; Park et al., 2014; Soh et al., 2009; Dhingra \& Jangra, 2014; Malini et al., 2011; Kwak et al., 2005). 더욱이, 생체 내에서 다양한 사이토카인, 성장인자, 부착물질, 효소 등의 발현 을 조절하는 것으로 알려져 있는 반면에 모유두 세포에 대한 연 구는 아직까지 미비하다. 따라서 본 연구는, UVA에 의한 산화적 스트레스가 유도하는 모유두 세포의 손상과 ellagic acid의 세 포 보호 기전에 대해 탐구하였다.

\section{Methods}

\section{1. 세포 배양 및 시료처리}

인간 모유두 세포(Innoprot, Spain)는 Dulbecco's Modified Eagle's Medium (DMEM; Hyclone, USA)에 10\% fetal bovine serum (FBS; Hyclone), 1\% penicillin $100 \mathrm{IU} / \mathrm{mL}$, streptomycin $100 \mu \mathrm{g} / \mathrm{mL}$ (Invitrogen, USA)을 혼합한 배양 배지를 이용하여 배양하였고, $37^{\circ} \mathrm{C}, 5 \% \mathrm{CO}_{2}$ 가 유지되는 세 포배양기 내에서 배양하였다. 순수정제된 분말형태의 ellagic acid (Sigma-Aldrich, USA)는 dimethyl sulfoxide (DMSO; Sigma-Aldrich)에 용해하여 세포에 처리하였다.

\section{UVA 조사}

UVA 조사에 앞서, 인간 모유두 세포를 세포 배양 접시에 균 일하게 뿌린 뒤 세포의 밀집도가 $90 \%$ 가 될 때까지 배양시킨 다. UVA 조사 직전, 배양배지를 제거해주고 phosphatebuffered saline (PBS) 용액을 이용하여 배양접시에 남아있 는 배지성분을 제거해준다. 새로운 $\mathrm{PBS}$ 용액을 배양 접시에
채우고, UVA를 조사하며 UVA 조사는 밀폐된 조사기기 내에 서 UVA 램프 (UVP, USA)를 사용하여 이루어졌다. 조사강 도는 fiberoptic spectrometer system USB2000 (Ocean optics, USA)를 사용하여 측정하였고, 조사가 끝난 직후, $\mathrm{PBS}$ 용액을 제거하고 배양배지를 넣어 배양기에서 24시간 동안 추가 배양한 이후에 실험에 사용하였다.

\section{3. 세포생존력 측정}

세포생존력은 water-soluble tetrazolium salt (WST-1) 방법(EZ-Cytox Cell Viability Assay Kit; Itsbio, Korea) 을 사용하여 측정하였다. 먼저 ellagic acid의 세포독성을 확 인하기 위해 인간 모유두 세포에 ellagic acid $(0-25 \mu \mathrm{M})$ 를 24 시간동안 처리하여 세포독성을 확인하였으며 다음으로 UVA에 의한 세포사멸 저해효과를 알아보기 위해 ellagic acid 를 6시간 전처리 후 UVA $\left(20 \mathrm{~J} / \mathrm{cm}^{2}\right)$ 를 조사하여 세포생존율 을 확인하였다. WST-1 시약은 배양중인 세포배양 접시에 첨 가하여 $37^{\circ} \mathrm{C}$ 에서 $1 \mathrm{~h}$ 배양 후, microplate reader (Bio-Rad, USA)를 이용하여 $490 \mathrm{~nm}$ 에서 흡광도를 측정하는 방법을 통 해 세포생존율을 확인하였다. 각각 3 회 반복측정 후 평균값과 표준편차를 도출하여 결과 분석에 사용하였다.

\section{4. 세포 내 활성산소 측정}

세포 내활성산소 측정에는 형광발광체인 2,7-dichlorofluorescin diacetate (DCFH-DA)을 사용하였다. 측정을 위해, 배양중인 세포에 $25 \mu \mathrm{M} \mathrm{DCFH}-\mathrm{DA}$ 를 첨가하여 $37{ }^{\circ} \mathrm{C}$ 에서 $1 \mathrm{~h}$ 동안 배 양하였으며, 발광강도는 BD FACSCalibur (flow cytometer; $\mathrm{BD}$ Biosciences, USA)를 사용하여 여기파장 $485 \mathrm{~nm}$, 들뜸 파장 $535 \mathrm{~nm}$ 로 측정하였다. $\mathrm{N}$-acetyl-cysteine (NAC)는 실 험의 양성대조군으로 사용되었다.

\section{RNA 추출 및 $\mathrm{CDNA}$ 제조}

배양이 끝난 실험세포는 Trizol reagent (Invitrogen, USA) 를 이용하여 용해 후, $0.2 \mathrm{~mL}$ chloroform (Sigma-Aldrich) 를 첨가하여 상온에서 반응시켰다. 반응이 끝나면 12000 $\mathrm{rpm}, 4^{\circ} \mathrm{C}$ 조건으로 20 분간 원심 분리하여 단백질이 포함된 하 등액과 $\mathrm{mRNA}$ 가 포함된 상등액을 분리하였고 상등액은 0.5 $\mathrm{mL}$ isopropanol을 첨가하여 다시 10 분간 상온에서 반응 시켰다. 10 분 후, $12000 \mathrm{rpm}, 4^{\circ} \mathrm{C}$ 조건으로 원심분리하여 $\mathrm{RNA}$ 를 침전시키고 $75 \%$ ethanol을 이용하여 침전된 $\mathrm{RNA}$ 를 헹구어 내고 상온에서 건조시켰다. 건조된 $\mathrm{mRNA}$ 는 diethylpyrocarbonate (DEPC; Sigma-Aldrich) water로 녹여 실험에 사용하였으며, 추출된 RNA는 MaestroNano ${ }^{\circledR}$ microspectrophotometer (Maestrogen, USA)을 이용하여 $260 \mathrm{~nm} / 280 \mathrm{~nm}$ 의 ratio 1.8 이상의 순도의 RNA만을 실 
험에 사용하였다. cDNA는 PCR tube에 $1 \mu \mathrm{g}$ RNA, $0.5 \mathrm{ng}$ oligo dT18, DEPC water를 total $10 \mu \mathrm{L}$ 로 제조 후 $70^{\circ} \mathrm{C}$ 에서 10 분간 처리하여 RNA 변성을 유도한 다음 $\mathrm{M}-\mathrm{MLV}$ reverse transcriptase (Enzynomics, Korea)을 이용하여 $37^{\circ} \mathrm{C}$ 에서 1 시간 반응시켜 $\mathrm{cDNA}$ 를 합성하였다.

\section{6. 실시간 유전자 정량 증폭 및 측정 (Quantitative real-time PCR)}

Ellagic acid로 인한 세포 수준의 유전자 발현을 분석하기 위해 실시간으로 유전자 증폭량을 측정하는 quantitative real-time PCR (qRT-PCR)을 사용하였다. Evagreen (Solis BioDyne, Estonia)을 사용하여 $\mathrm{mRNA}$ 발현량을 실시간으로 분석하였으 며, 결과분석에는 Line-Gene K software (BioER, China)를 이 용하였다. 실험에 사용된 primer 서열은 Table 1 과 같다.

\section{7. 노화세포 측정}

노화세포 측정은 노화세포에서 발현하는 $\beta$-galactosidase 만을 선택적으로 염색하는 SA- $\beta$-galactosidase assay (senescence detection kit; Biovision, USA)를 사용하였다. 먼저, 배양이 끝난 실험세포는 배지를 제거하고 PBS 로 헹굼으로 써 잔여배지성분을 한번 더 제거해준다. 이 후에, 세포고정용액 $0.5 \mathrm{~mL}$ 을 첨가하여 상온에서 15 분간 반응시켜 세포를 고정화시 키고, 이어서 $20 \mathrm{mg} / \mathrm{mL} \mathrm{X-gal} \mathrm{염색시약} \mathrm{(staining} \mathrm{solution}$ $470 \mu \mathrm{L}$, staining supplement $5 \mu \mathrm{L}$, dimethylformamide $25 \mu \mathrm{L}$ )을 $0.5 \mathrm{~mL}$ 씩 첨가하여 $37^{\circ} \mathrm{C}$ 에서 $24 \mathrm{~h}$ 반응시킨다. 24 시간 후, 염색된 세포는 PBS로 가볍게 헹구어 준 뒤 형광현미 경(AxioVert 200 inverted microscope; ZEISS, Germany) 을 사용하여 염색된 세포 수를 측정하고 분석하였다.

\section{8. 세포이동력 측정}

세포의 이동능을 확인하기 위해 세포이동력을 측정하는 실험을 실시하였다. 모유두 세포를 세포배양접시에 균일하 게 뿌린 후, 하룻밤 동안 배양기 내에서 세포 밀집도가 $90 \%$ 가 될 때까지 배양한다. 이후에 $2 \% \mathrm{FBS}$ 가 포함된 배지로 배 양배지를 교체하여 $24 \mathrm{~h}$ 추가배양을 한다. $24 \mathrm{~h}$ 뒤, 세포에 ellagic acid를 처리하는 실험을 진행하고, $200 \mu \mathrm{L}$ pipette tip (Fisher Scientific, USA)을 사용하여 세포배양접시 내에

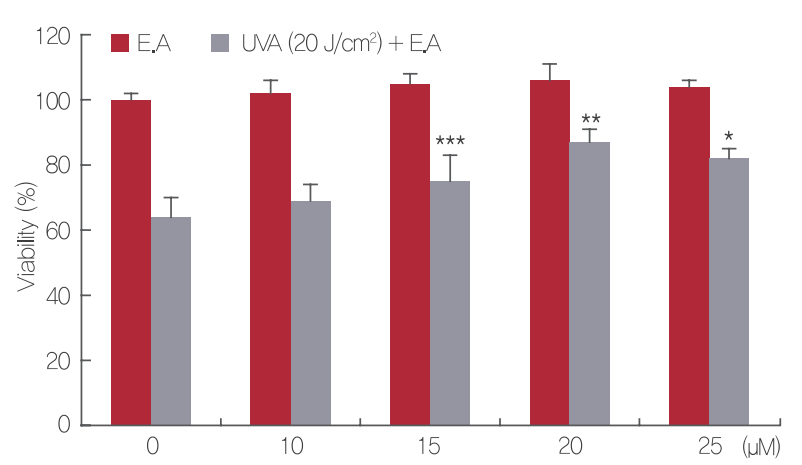

Figure 1. Determination of HDPC viability using WST-1 assay . The black panels indicate the cytotoxicity of ellagic acid on HDPC at the indicated concentrations. The white panels indicate the protective effects of ellagic acid on HDPC cytotoxicity induced by UVA $\left(20 \mathrm{~J} / \mathrm{cm}^{2}\right)$. Cell viability was expressed as a percentage of control, and values represent mean \pm S.D. ${ }^{*} p \leq .05,{ }^{* *} p \leq .01$, and ${ }^{* * *} p \leq .001$ compared with irradiated cells without ellagic acid.

형성된 단일세포층을 3 회 긁어난다. 이후 $24 \mathrm{~h}$ 동안 $10 \% \mathrm{FBS}$ 가 포함된 배양배지로 세포배양을 진행하며, 광학현미경(Olympus Microscope System IX51; Olympus, Japan)을 이용하 여 이미지를 촬영하였다. 촬영한 이미지는 이미지분석프로그 램인 Image Pro Plus 6.0 (Media Cybernetics)을 사용하여 $\mu \mathrm{m}$ 단위로 세포이동거리를 측정하였다.

\section{9. 통계}

본 연구의 모든 실험은 독립적으로 3 회 실시하였으며, 각 실험에 대하여 student t-test를 이용하여 $\mathrm{p}$-value를 구하고 SPSS version 17.0 을 사용하여 분석하였다. $\mathrm{p}$-value 값이 $0.05,0.01,0.001$ 이하인 경우 통계적으로 유의하다고 분석 하였다(*p $\left.\leq .05, * * p \leq .01,{ }^{* * *} p \leq .001\right)$.

Table 1. Primer list using quantitative real-time PCR

\begin{tabular}{lll}
\hline Gene & Forward $\left(5^{\prime} \rightarrow 3^{\prime}\right)$ & Reverse $\left(5^{\prime} \rightarrow 3^{\prime}\right)$ \\
\hline CAT & ATGGTCCATGCTCTCAAACC & CAGGTCATCCAATAGGAAGG \\
$T N F-\alpha$ & CCCAGGGACCTCTCTCTAATC & GGTTTGCTACAACATGGGCTACA \\
$I L-1 \beta$ & GATCCACACTCTCCAGCTGCA & CAACCAACAAGTGATATTCTCCATG \\
$I L-6$ & TAACAGTTCCTGCATGGGCGGC & AGGACAGGCACAAACACGCACC \\
$\beta-$ actin & GGATTCCTATGTGGGCGACGA & CGCTCGGTGAGGATCTTCATG \\
\hline
\end{tabular}



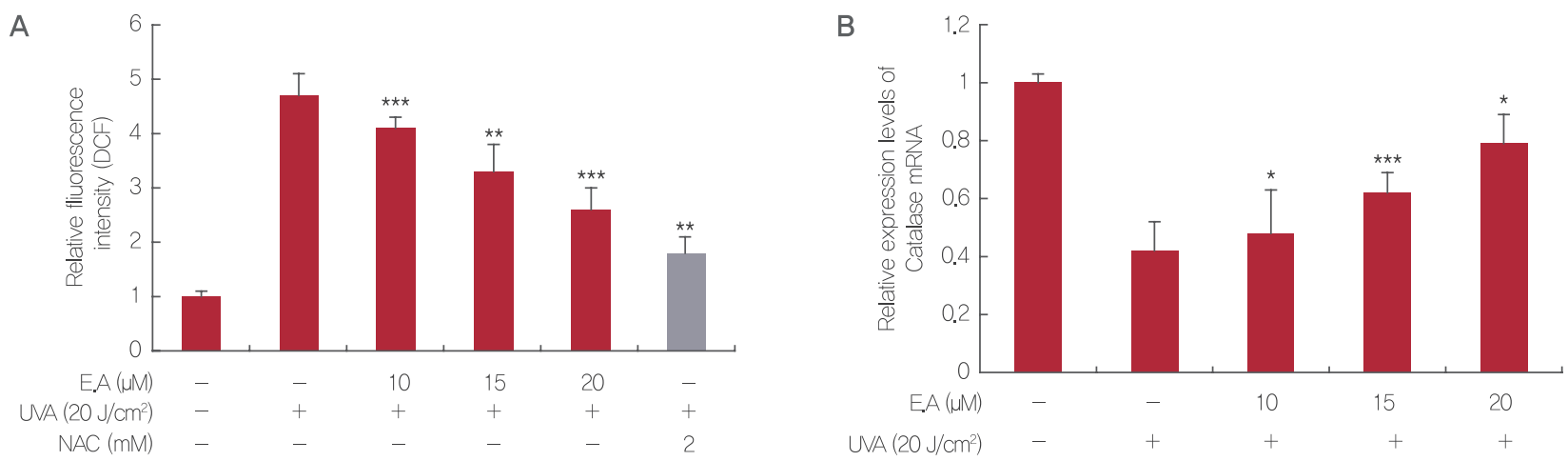

Figure 2. Effects of ellagic acid on antioxidant defense mechanism in HDPC cellular levels.

(A) UV-induced intracellular ROS scavenging effects of ellagic acid via DCFH-DA fluorescence dye. (B) Effect of ellagic acid on CAT gene expression in UVA-irradiated HDPCs. Gene expression was quantitatively evaluated by real-time PCR with the $2^{-\Delta \Delta C t}$ method, and data presented normalized to $\beta$-actin. ${ }^{*} p \leq .05 ;{ }^{* *} p \leq .01 ;{ }^{* * *} p \leq .001$ compared with irradiated cells without ellagic acid.

\section{Results and Discussion}

\section{HDPCs에서 ellagic acid의 UVA에 의한 세포독성 보호효과}

먼저 인간 모유두 세포에서 ellagic acid에 의한 세포독성 을 확인하였다. Ellagic acid를 각각 $0,10,15,20,25 \mu \mathrm{M}$ 로 처리하여 24시간 배양 후 세포생존율을 측정한 결과, 실험농 도에서는 모두 독성이 나타나지 않았다(Figure 1). 이어서, 동 일한 농도의 ellagic acid를 전처리한 세포에 UVA를 조사하 여 ellagic acid의 세포 보호효과를 알아보는 실험을 진행한 결과, ellagic acid를 각각 $15,20,25 \mu \mathrm{M}$ 전처리한 실험군 에서 UVA 조사로 인해 $64 \%$ 까지 감소한 세포 생존율이 75 , $87,82 \%$ 로 세포사멸이 감소한 것을 확인할 수 있었다. 따라 서, UVA가 유도하는 세포 독성 및 세포생장 저해에 ellagic acid의 농도 의존적인 세포 보호효과를 확인하였다.

\section{UVA로 인해 생성된 활성산소에 대한 ellagic acid의 항산화 효과}

선행연구결과에 따르면 UVA는 세포 내 활성산소의 생성을 유 도하여 산화적 스트레스와 DNA 손상을 일으킨다고 보고되어 있다(Maverakis et al., 2010; Aroun et al., 2012; Jaszewska et al., 2013). 따라서 본 연구자는 앞서 수행한 세포독성 실 험을 바탕으로, UVA로 인한 세포독성을 보호하는 ellagic acid의 효과가 세포 내 활성산소 생성을 저해하는 기전 과 무관하지 않을 거라는 가설을 내리고 이를 입증하기 위 해 ellagic acid의 항산화 효과를 확인하는 실험을 하였다. 그 결과, UVA로 인해 생성된 세포 내 활성산소가 ellagic acid 전처리 농도 의존적으로 감소한 것을 확인할 수 있었으며, 본 실험의 양성대조군으로 사용된 $2 \mathrm{mM} \mathrm{NAC}$ 와 비교하였을 때에도 ellagic acid가 현저한 활성산소 생성 저해효과를 나
타냄을 알 수 있다(Figure 2A), 더불어, DCFH-DA를 사용 한 실험에서 ellagic acid는 실험을 위해 설정한 모든 농도 $(10,15,20 \mu \mathrm{M})$ 에서 유의한 결과를 나타내었다. 이어서, 대 표적인 세포 내 항산화 기전의 하나인 $\mathrm{CAT}$ 의 전사활성변화 를 알아보기 위해 $\mathrm{qRT}-\mathrm{PCR}$ 을 이용하여 CAT mRNA 발현을 알아보았다. CAT는 산화적 스트레스가 가해졌을 때 세포 내 항산화 작용을 유도하는 결정적인 효소 중 하나로 본 실험에 서는 UVA 조사에 의해 세포 내 $\mathrm{mRNA}$ 수준이 줄어들었으나, ellagic acid를 전처리함에 따라 농도 의존적으로 mRNA 수준 이 증가한 것을 확인 하였다(Figure $2 \mathrm{~B})$. 상기 결과로 말미암아, $\mathrm{UVA}$ 는 인간 모유두 세포 내에서 활성산소를 생성하지만 활성 산소의 생성을 저해하거나 세포 내 항산화 작용을 활성화 시 키는 ellagic acid의 직접 혹은 간접적인 작용을 통하여 산화 적 스트레스가 경감되는 것을 확인하였다. 본 연구결과를 통해 ellagic acid가 UVA가 유도하는 산화적 스트레스로부터 세포 를 보호하는 효과가 있음을 입증하였다.

\section{UVA로 인해 유도된 염증반응에 ellagic acid의 염증생성기전 저해 효과}

UVA 조사로 인해 유도되는 염증생성기전에 ellagic acid가 미치는 영향을 알아보기 위하여, 대표적인 염증유발 사이토카인 (pro-inflammatory cytokine)인 tumor necrosis factor- $\alpha$ (TNF- $\alpha$ )와 interleukin-6 (IL-6)의 mRNA 발현수준을 $\mathrm{qRT}-\mathrm{PCR}$ 을 통해 확인하였다. TNF- $\alpha$ 는 생리적 혹은 병리 적 조건에서의 염증을 촉진하고, 세포 종류에 따라 세포 사 멸, 증식 및 분화를 포함하는 다양한 반응을 유도할 뿐만 아 니라, 대식세포와 NK세포(natural killer cell) 등을 활성화 시키며 세포 표현형의 변화를 야기한다(Park et al, 2002; Zheng et al., 2016). 게다가 자가분비성장인자(autocrine 


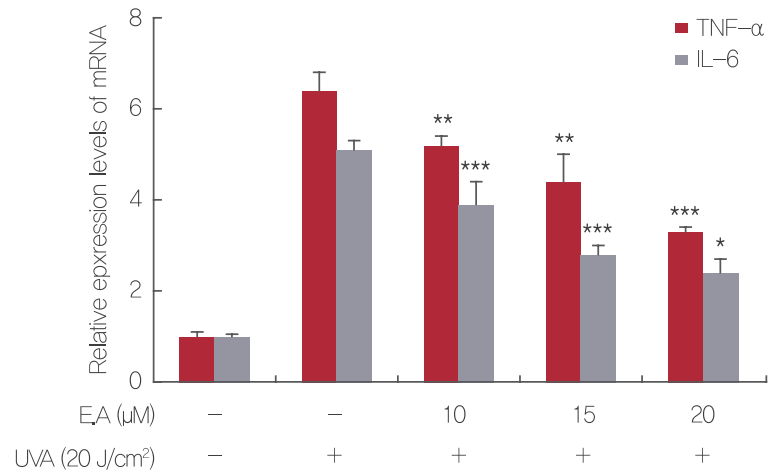

Figure 3. Suppression effects of ellagic acid on immune response via regulating pro-inflammatory cytokines expression.

$T N F-\alpha$ and $L-6$ was used in this experiments, and each gene expression was normalized to $\beta$-actin. Gene expression was estimated using quantitative realtime PCR and expression was calculated using $2^{-\Delta \Delta C t}$. ${ }^{*} p \leq .05 ;{ }^{* *} p \leq .01 ;{ }^{* * *} p \leq .001$ compared with irradiated cells without ellagic acid.

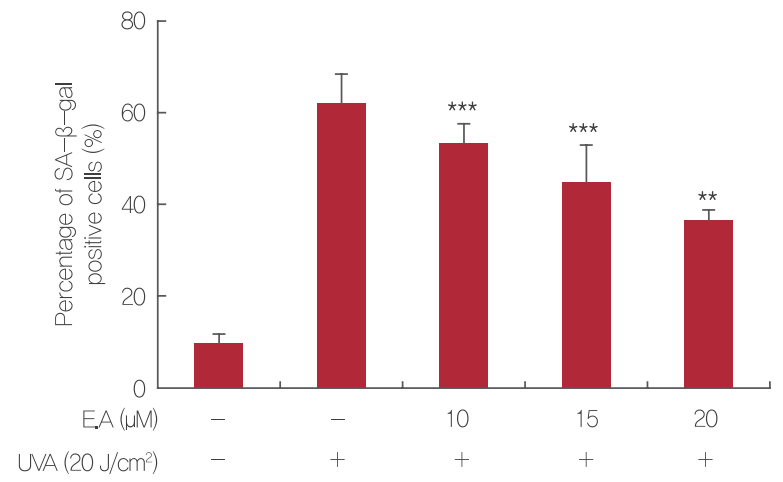

Figure 4. Inhibition effects of ellagic acid on cellular senescence in HDPCs.

Cellular senescence measured using $S A-\beta-$ gal assay. ${ }^{* *} p \leq .01 ;{ }^{* * *} p \leq .001$ compared with irradiated cells without ellagic acid.

growth factor)의 억제제로 작용하기도 하면서 모낭에서는 모발의 성장을 억제하고 모낭의 표현형을 모구 퇴행기 형태와 유사하게 변화시키는 것으로 알려져 있다(Laurikkala et al., 2002). IL-6는 급성 염증 반응을 유도하며 모낭에서는 기질 세포 증식을 저해하고 모발의 퇴화기를 가속화시키는 것으로 보고된 바 있다(Kwack et al., 2012). Figure 3에서 보는 바 와 같이, 인간 모유두 세포에 ellagic acid를 $10,15,20 \mu \mathrm{M}$ 전 처리하고 $\mathrm{UVA}$ 를 조사한 결과, UVA로 인해 $T N F-\alpha$ 와 $I L-6$ 의 mRNA 발현이 무처리 대조군에 비하여 각각 $6.4( \pm 0.4)$ 배, $5.1( \pm 0.2)$ 배 증가한 것을 확인하였으며 ellagic acid 전처 리 농도 의존적으로 유의적인 감소가 나타났다. 이러한 결과는,

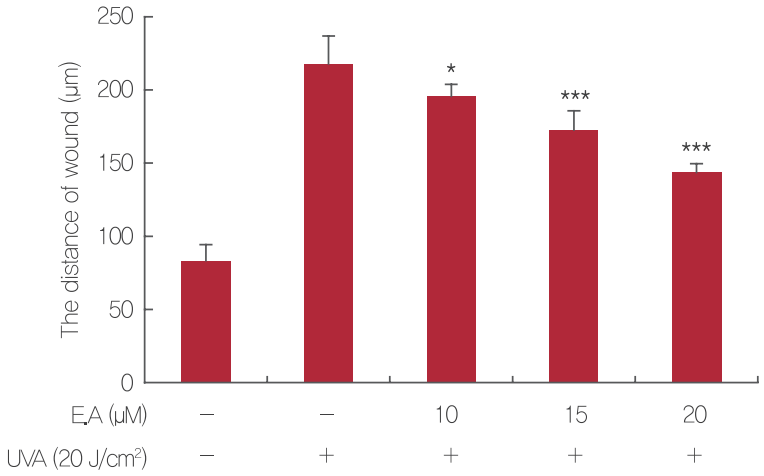

Figure 5. Effect of ellagic acid on cell migration activity under UVA-irradiated condition.

The scratch images captured after $24 \mathrm{~h}$, using an Olympus IX51 microscope. ${ }^{*} p \leq .05 ;{ }^{* *} p \leq .01 ;{ }^{* * *} p \leq .001$ compared with irradiated cells without ellagic acid.

ellagic acid가 UVA로 인해 유도되는 면역반응과 염증생성기 전에 있어서 세포보호효과를 가짐을 입증하며, 특히 모유두 세 포에서의 결과로 모낭뿐만 아니라 모발의 형성주기에도 영향을 미칠 수 있다는 점을 제시하고 있다.

\section{UVA 처리된 모유두 세포에서 ellagic acid가 세포노화에 미치는 영향}

선행연구결과에 따르면, UVA는 세포 내 활성산소의 생성을 야기하며 세포의 노화를 유도한다(Yang et al., 2015). 따라 서 본 연구자는 인간 모유두 세포에서 UVA 조사로 인해 발생 하는 세포노화에 ellagic acid가 미치는 영향을 시험해보았 다. SA- $\beta$-gal kit를 이용하여 세포노화를 확인한 결과, 20 $\mathrm{J} / \mathrm{cm}^{2}$ 로 UVA를 조사하였을 때, $60 \%$ 이상의 세포에서 세포 노화가 관측되었다. 그러나 ellagic acid를 $10,15,20 \mu \mathrm{M}$ 처 리하였을 때 농도 의존적으로 세포노화의 감소가 나타났으 며, 이러한 결과는 실험농도 전체에서 유의적으로 확인되었다 (Figure 4). 따라서 본 연구결과를 바탕으로 인간 모유두 세 포에서 UVA가 유도하는 세포노화를 ellagic acid가 효과적으 로 저해하는 것을 알 수 있었으며 추후 연구를 통해 구체적인 기전이 밝혀진다면 세포 노화 저해 효과에 대해 체계적인 결과 보고가 가능할 것으로 사료된다.

\section{UVA 처리된 인간 모유두 세포에서 ellagic acid가 세포 이동력에 미치는 영향}

세포의 재생 및 이동변화를 확인하기 위하여 세포 이동력 확 인 실험을 수행하였다. 실험 수행 후 24 시간이 지나 확인한 세 포의 이동능은 단일세포층을 $200 \mu \mathrm{L}$ pipette tip을 이용하여 긁어냄으로써 생성된 무세포 영역(스크레치)이 얼마나 변화가 있는지, 광학현미경과 이미지분석프로그램을 사용하여 측정하 
였으며 결과는 Figure 5 와 같다. UVA를 조사한 실험군에서는 무처리 대조군에 비해 스크레치 간격이 2.5 배 이상 넓게 나타 나 세포활성이 확연히 감소하고, 세포의 이동능력이 현저하게 줄어든 것을 확인할 수 있었다. 이어서, ellagic acid를 전처 리하고 UVA를 조사한 실험군의 경우 ellagic acid 농도 의존 적으로 감소한 스크레치 간격을 나타냈다. 이러한 결과를 통 해, ellagic acid가 UVA로 인해 인간 모유두 세포에 유발하 는 스트레스를 감소시키며 세포의 활성과 이동능에도 영향을 미치는 것을 입증하였다.

\section{Conclusion}

본 연구는 UVA 조사로 인해 산화적 스트레스가 유발된 인 간 모유두 세포에서 ellagic acid의 세포보호 효과를 확인한 것 으로, 세포독성, 활성산소 생성, 염증성 면역반응, 세포노화와 세포의 이동능에 대해 실험하여 결과를 얻었다. 먼저 세포 생 존력을 측정한 실험결과, ellagic acid는 UVA에 의한 세포독 성을 농도의존적으로 저해하였으며 UVA 조사로 인해 유발되 는 세포 내 활성산소 또한 양성 대조군인 NAC에 비하여 세포 독성이 없는 농도에서 효과적으로 소거하는 것을 확인할 수 있 었다. 더불어, 대표적인 항산화 효소인 CAT 유전자 발현을 조 절하여 세포 내 활성산소에 대하여 직접 혹은 간접적으로 항산 화 기전에 영향을 미치는 것을 입증하였다. 다음으로 UVA 조 사로 인해 유도되는 염증성 면역반응에 미치는 영향을 확인 하기 위하여 염증성 사이토카인인 TNF- $\alpha$ 와 $\mathrm{IL}-6$ 의 유전자 발현을 실험한 결과, 각각 정도의 차이는 있었지만 본 실험에 적용한 ellagic acid의 농도에 의존적으로 발현이 저해되는 효 과를 확인하여 염증생성기전을 조절함을 확인하였다. 이어서 세포노화와 세포의 이동능 변화를 알아보는 실험을 통해, 추 가적으로 노화억제 효과와 자극에 의한 세포활성 감소를 효 과적으로 저해시키는 것을 확인할 수 있었다. 결과적으로, 본 연구 결과를 통하여 UVA 조사로 인해 산화적 스트레스가 유 발된 인간 모유두 세포에서 ellagic acid의 세포보호 효과를 입증하였다.

\section{References}

Abuelsaad AS, Mohamed I, Allam G, Al-Solumani AA. Antimicrobial and immunomodulating activities of hesperidin and ellagic acid against diarrheic Aeromonas hydrophila in a murine model. Life Sciences, 93: 714-722, 2013.
Aroun A, Zhong JL, Tyrrell RM, Pourzand C. Iron, oxidative stress and the example of solar ultraviolet A radiation. Photochemical \& Photobiological Sciences, 11: 118-134, 2012.

Bickers DR, Athar M. Oxidative stress in the pathogenesis of skin disease. Journal of Investigative Dermatology, 126: 2565-2575, 2006.

Cha HJ, Kim YJ. Procyanidin B1 regualtes matrixmetalloprotease 1 mRNA expression using JNKAP1-TRE axis in normal human dermal fibroblasts. Korean Journal of Aesthetics and Cosmetology, 13: 761-765, 2015.

Choi SJ, Cho AR, Jo SJ, Hwang ST, Kim KH, Kwon OS. Effects of glucocorticoid on human dermal papilla cells in vitro. The Journal of Steroid Biochemistry and Molecular Biology, 135: 24-29, 2013.

Dhingra D, Jangra A. Antiepileptic activity of ellagic acid, a naturally occurring polyphenolic compound, in mice. Journal of Functional Food, 10: 364-369, 2014.

Driskell RR, Clavel C, Rendl M, Watt FM. Hair follicle dermal papilla cells at a glance. Journal of Cell Science, 124: 1179-1182, 2011.

Gao J, DeRouen MC, Chen CH, Nguyen M, Nguyen NT, Ido H, Harada K, Sekiguchi K, Morgan BA, Miner $\mathrm{JH}$, et al. Laminin-511 is an epithelial message promoting dermal papilla development and function during early hair morphogenesis. Genes \& Development, 22: 2111-2124, 2008.

García-Niño WR, Zazueta C. Ellagic acid: pharmacological activities and molecular mechanisms involved in liver protection. Pharmacological Research, 97: 84-103, 2015.

Inui S, Fukuzato Y, Nakajima T, Yoshikawa K, Itami S. Identification of androgen-inducible TGF-beta1 derived from dermal papilla cells as a key mediator in androgenetic alopecia. The Journal of Investigative Dermatology Symposium Proceedings, 8: 69-71, 2003.

Jaszewska E, Soin M, Filipek A, Naruszewicz M. UVAinduced ROS generation inhibition by Oenothera paradoxa defatted seeds extract and subsequent cell death in human dermal fibroblasts. Journal of Photochemistry and Photobiology B: Biology, 126: 42-46, 2013.

Khanduja KL, Avti PK, Kumar S, Mittal N, Sohi KK, 
Pathak CM. Anti-apoptotic activity of caffeic acid, ellagic acid and ferulic acid in normal human peripheral blood mononuclear cells: a Bcl-2 independent mechanism. Biochimica et Biophysica Acta - General subjects, 1760: 283-289, 2006.

Kim KB, Jo A, Cha HJ, Shin SH, Lee JJ, Lee HK, An IS. Synergetic effects of sericin and alpha-mangostin on anti-wrinkle effects. Korean Journal of Aesthetics and Cosmetology, 13: 729-734, 2015.

Kwack MH, Ahn JS, Kim MK, Kim JC, Sung YK. Dihydrotestosterone-inducible $\mathrm{IL}-6$ inhibits elongation of human hair shafts by suppressing matrix cell proliferation and promotes regression of hair follicles in mice. Journal of Investigative Dermatology, 132: 4349, 2012.

Kwak HM, Jeon SY, Sohng BH, Kim JG, Lee JM, Lee KB, Jeong HH, Hur JM, Kang YH, Song KS. Betasecretase (BACE1) inhibitors from pomegranate (Punica granatum) husk. Archives of Pharmacal Research, 28: 1328-1332, 2005.

Laurikkala J, Pispa J, Jung HS, Nieminen P, Mikkola M, Wang X, Saarialho-Kere U, Galceran J, Grosschedl R, Thesleff I. Regulation of hair follicle development by the TNF signal ectodysplasin and its receptor edar. Development, 129: 2541-2553, 2002.

Li TM, Chen GW, Su CC, Lin JG, Yeh CC, Cheng KC, Chung JG. Ellagic acid induced p53/p21 expression, G1 arrest and apoptosis in human bladder cancer T24 cells. Anticancer Research, 25: 971-979, 2005.

Malini P, Kanchana G, Rajadurai M. Antibiabetic efficacy of ellagic acid in streptozotocin-induced diabetes mellitus in albino wistar rats. Asian Journal of Pharmaceutical and Clinical Research, 4: 124-128, 2011.

Maverakis E, Miyamura Y, Bowen MP, Correa G, Ono Y, Goodarzi H. Light, including ultraviolet. Journal of Autoimmunity, 34: 247-257, 2010.

Park JG, Yuk Y, Rhim H, Yi SY, Yoo YS. Role of p38 MAPK in the regulation of apoptosis signaling induced by TNF-alpha in differentiated PC12 cells. Journal of Biochemistry and Molecular Biology, 35: 267272. 2002.

Park SW, Kwon MJ, Yoo JY, Choi HJ, Ahn YJ. Antiviral activity and possible mode of action of ellagic acid identified in Lagerstroemia speciosa leaves toward human rhinoviruses. BMC Complementary and Alternative Medicine, 14: 171-178, 2014.

Plundrich N, Grace MH, Raskin I, Ann Lila M. Bioactive polyphenols from muscadine grape and blackcurrant stably concentrated onto protein-rich matrices for topical applications. International Journal of Cosmetic Science, 35: 394-401, 2013.

Rehman MU, Tahir M, Ali F, Qamar W, Lateef A, Khan R, Quaiyoom A, Oday-O-Hamiza, Sultana S. Cyclophosphamide-induced nephrotoxicity, genotoxicity, and damage in kidney genomic DNA of Swiss albino mice: the protective effect of ellagic acid. Molecular and Cellular Biochemistry, 365: 119-127, 2012.

Shin H, Cho AR, Kim DY, Munkhbayer S, Choi SJ, Jang S, Kim SH, Shin HC, Kwon O. Enhancement of human hair growth using Ecklonia cava polyphenols. Annals of Dermatology, 28: 15-21, 2016.

Soh PN, Witkowski B, Olagnier D, Nicolau ML, GarciaAlvarez MC, Berry A, Benoit-Vical F. In vitro and in vivo properties of ellagic acid in malaria treatment. Antimicrobial Agents and Chemotherapy, 53: 1100-1106, 2009

Soong Y, Barlow PJ. Quantification of gallic acid and ellagic acid from longan (Dimocarpus longan Lour.) seed and mango (Mangifera indica L.) kernel and their effects on antioxidant activity. Food Chemistry, 97: 524-530, 2006.

Vile GF, Tyrrell RM. UVA radiation-induced oxidative damage to lipids and proteins in vitro and in human skin fibroblasts is dependent on iron and singlet oxygen. Free Radical Biology and Medicine, 18: 721-730, 1995.

Wondrak GT, Roberts MJ, Cervantes-Laurean D, Jacobson MK, Jacobson EL. Proteins of the extracellular matrix are sensitizers of photooxidative stress in human skin cells. Journal of Investigative Dermatology, 121: 578-586, 2003.

Yang SR, Park JR, Kang KS. Reactive oxygen species in mesenchymal stem cell aging: implication to lung diseases. Oxidative Medicine and Cellular Longevity, 2015: 486263, 2015. 
Zahin M, Ahmad I, Gupta RC, Aqil F. Punicalagin and ellagic acid demonstrate antimutagenic activity and inhibition of benzo[a]pyrene induced DNA adducts. Biomed Research International, 2014: 467465, 2014.
Zheng C, Zhou XW, Wang JZ. The dual roles of cytokines in Alzheimer's disease: update on interleukins, TNF- $\alpha$, TGF $-\beta$ and IFN $-\gamma$. Translational Neurodegeneration, 5: 7-21, 2016. 


\section{국문초록}

\section{UVA가 유도하는 산화적 스트레스에 Ellagic Acid가 미치는 인간 모유두 세포 보호효과}

김경숙 ${ }^{1}$ 한송희 ${ }^{2}$, 안인숙 ${ }^{3}$, 안규중 ${ }^{2 *}$

${ }^{1}$ 건국대학교 생물공학과, 서울, 한국

${ }^{2}$ 건국대학교 의학전문대학원 피부과학교실, 서울, 한국

${ }^{3}$ 한국피부임상과학연구소, 충청북도 청주시, 한국

목적: 태양광을 구성하는 성분 중 하나인 UVA는 피부에서 활성산소(reactive oxygen species, ROS)를 생산하고 피부 깊숙히 침투 할 수 있는 능력을 가지고 있다. 이러한 특성은 진피층에 광분해생성물이나 세포노화, 세포 사멸, 염증, 유전자 발현 변화와 같은 산화적 스트레스를 유발한다. 따라서, UVA는 피부를 자극하는 주요 외부인자로 여겨지고 있다. 본 연구의 목적은 UVA에 의한 자극에 ellagic acid의 항산화 및 항염 효과를 인간 모유두 세포를 이용하여 확인하였다.

방법: 세포 생존력은 WST-1 방법을 사용하여 수행하였으며, DCFH-DA 을 이용하여 세포 내 활성산소 소거능을 연구하였다. 본 연구에서 시험한 모든 mRNA 발현은 $\mathrm{qRT}-\mathrm{PCR}$ 을 통해 분석하였으며 세포노화는 SA- $\beta$-gal 세트를 사용하여 조사하였다. 세포이동능 분석을 통해 ellagic acid가 $\mathrm{HDPC}$ 의 이동능에 미치는 영향을 알아보았다.

결과: Ellagic acid $25 \mu \mathrm{M}$ 까지 세포독성은 확인되지 않았으며, UVA로 인한 세포독성에 ellagic acid가 보호하는 효과를 확인하였다. 더불어, 항산화 효소인 CAT의 유전자 발현변화를 유도하는 효과와 세포 내 활성산소를 소거하는 효과를 실험을 통해 입증하였다. 이뿐만 아니라, UVA 조사로 인해 발현이 증가한 염증유도인자, TNF- $\alpha, \mathrm{IL}-6$ 의 mRNA 발현 수준을 조절하는 것으로 나타났으며 UVA로 인해 손상된 세포의 세포 이동능을 보호하는 것에도 유의적인 효과가 있음을 확인할 수 있었다.

결론: 본 연구결과는 ellagic acid가 UVA로 인해 유도되는 산화적 스트레스를 보호하는 효과를 인간 모유두 세포를 이용하여 입증 하였다.

핵심어: UVA, 산화적 스트레스, 인간 모유두 세포, 염증, Ellagic acid

\section{참고문헌}

김기쁨, 조아령, 차화준, 신상훈, 이정주, 이현경, 안인숙. Sericine과 alpha-mangostin의 주름개선 상승효과. 대한피부미용학회지, 13: 729-734, 2015.

차화준, 김영주. 인간진피섬유아세포에서 코코아 주요성분인 procyanidin B1이 JNK-AP1-TRE axis를 통한 matrixmetalloprotease 1 발현조절에 미치는 영향. 대한피부미용학회지, 13: 761-765, 2015. 


\section{中文摘要}

\section{Ellagic Acid对UVA照射诱导的人体头发毛乳头细胞氧化应激性损伤的保护作用}

金敬淑 ${ }^{1}$, 韓松希 $^{2}$, 安仁淑 ${ }^{3}$, 安圭重 $2 *$

建国大学校生物工学科, 首尔, 韩国

2建国大学医科大学皮肤科, 首尔, 韩国

3韩国皮肤临床科学研究所, 忠淸北道 清州市, 韩国

目的: UVA可以深入皮肤深层诱发氧化应激，通过研究确认Ellagic acid 对UVA照射诱导氧化应激的人体毛乳头细胞的抗氧化及 抗炎效果。

方法: 细胞生存力通过 WST-1 方法确认, 利用 DCFH-DA 研究细胞内活性氧的消除能力。所有 MRNA 表达通过qRT-PCR 方法 分析, 细胞老化利用SA- $\beta$-gal系列调查。通过细胞移动能力分析, 探讨ellagic acid对 HDPC 细胞的移动能力产生的影响。 结果: Ellagic acid 的浓度在 $25 \mu \mathrm{M}$ 以下时, 没有显现细胞毒性。Ellagic acid 对 UVA 诱发毒性的细胞具有保护作用。通过实 验也证明了 ellagic acid 诱导抗氧化酶，即，过氧化氢酶基因的表达和消除细胞内活性氧。除此之外，还发现 ellagic acid 对 调节UVA照射而增加的炎症基因, TNF- $\alpha$ 和IL-6的基因表达具有调节效果以及对保护UVA 损伤细胞的细胞移动能力具有统计 意义的效果。

结论: 通过实验证明了ellagic acid 对UVA诱导氧化应激的人体毛乳头细胞，具有抗氧化及抗炎效果。

关键词: UVA，氧化应激，人体毛乳头细胞，炎症，Ellagic acid 